Reinisch J. The Perils of Peace: The Public Health Crisis in Occupied Germany. Oxford (UK): OUP Oxford; 2013 Jun 6.

\title{
Chapter 8 The Forgotten Zone: Public Health Work in the French Occupation Zone
}

\section{Plans}

By spring 1945, it was clear that all the different French political factions wanted to be represented in the occupation. Among them, very few voices called for reconciliation with the defeated enemy. After France's liberation, nationalist slogans were used across the political spectrum, including the ever-popular 'Le Boche payera' - familiar to French and Germans alike from the demands for reparations at Versailles in 1919. ${ }^{1}$ Within the body which coordinated the French Resistance and oversaw its work, the National Resistance Council (Conseil National de la Résistance, CNR), there were different visions of France's future tasks in Germany and beyond. What separated, and united, these different approaches had huge implications for public health work in the French occupation project.

One of the most influential French analysts of the German problem was the Sorbonne historian Edmond Vermeil. His work had a number of implications for French occupation plans: Germany would continue to strive for domination, he predicted, unless permanently prevented by force, and so the occupation had to be a long-term project. A distinction between the Nazi leadership and the wider population was meaningless, since reform could not be achieved just by the removal of leaders; it would have to change deeply rooted traditions, institutions, habits of thought and sentiments. The 'essential task in the political constitution of post-war Germany', Vermeil advised, had to be to “ "dePrussianize" the country, transferring its political centre of gravity from the North-east to the South-west', now under French (and American) occupation. This solution was not only to neutralize Prussia and its intellectual and military heritage from German life (and, incidentally, boost the importance of France), but also had 'the advantage of placing the new centre of gravity in the neighbourhood of, if not under the direct control of or in close dependence on, the United Western Nations'.

France's occupation project combined reforms within Germany with a reshaping of the political map of Europe. Future peace and security, Vermeil insisted, depended on whether Germany was firmly tied into (Western) Europe. 'The Western democracies' had to counter Nazism through the creation of a Europe 'at once diverse and united, between the Atlantic eventually dominated by the United States and a Russia at full tide'. The Continent must be reshaped 'under some constitution conformable to the interests of our civilisation, [as the] offspring of Western humanism', where a regenerated Germany could 'find herself a niche'. It should be a 'Europe regenerated by Germany's own regeneration and by the establishment of normal relations between Germany and the Continental countries surrounding her, between the Continent and Great Britain, and between the British Empire and the French'. 3 To this end it was crucial that the Western Allies created a firm and durable union themselves. '[I]n short', as A. L. Rowse put it in a review of Vermeil, the problem of Germany was 'the problem of Europe'.

Charles de Gaulle also saw clear and long-standing continuities in the history and psychology of Germany, to whom France had fallen victim three times. But where Vermeil argued that cutting up Germany into states or regions would reintroduce fragmentation and 'fatal pluralism', which had given rise to Germany's 'morbid nationalism' in the first place, de Gaulle insisted that only decentralization would teach the Germans a lesson and ensure future French security. ${ }^{5}$ Defeat and temporary exhaustion of Germany were not a sufficient guarantee. The 'first condition necessary to prevent Germany from returning to its bad ways', he thought, was the 'abolition of a centralised Reich'. He explained:

if each of the states within the German federation could exist by itself, govern itself in its own way, handle its own interests, there would be every likelihood that the federation as a whole would not be led to subjugate its neighbors. This would be even more likely if the Ruhr, that arsenal of strategic materiel, were given a special status under international control. Further, the Rhineland would, of course, be occupied by French, British, Belgian and Dutch armies ... Lastly, there was every reason to suppose that the Saar, retaining its German character, would be transformed into a separate state and united to France by trade agreements which would settle the question of our reparations in terms of coal. Thus the German federation, recovering its diversity and turning its eyes toward the west, would lose the means of war but not those of its own development. In addition, none of its fragments would be annexed by the French, thus leaving the door to reconciliation open. 6 
He supported a return to some of the pillars of French foreign policy after 1919: the assumptions that Saar coal and Ruhr industrial resources should be used to rebuild and expand France's economy; Prussia should be dismantled; the Rhineland should be removed from Germany and put under French control; and the area around the Ruhr should be placed under international control. Georges Bidault — president of the CNR, and co-founder of the French Christian Democratic Party (Mouvement Républicain Populaire, MRP), and foreign minister after 1944 - helped to put these priorities into practice, ${ }^{7}$ as did General Pierre Koenig, French commander-in-chief, military governor, representative on the Allied Control Council (ACC) in Berlin and a close ally of de Gaulle.

Socialist groups shared some of these ideas, but they placed greater emphasis on the reform and reintegration of Germany into a wider European framework. They were also less vocal about the desirability of revenge. A number of French socialists argued for balance: neither 'generous but facile indulgence' of the Germans, nor retribution of a kind that would 'thrust them back into a past that has for ever vanished', was in France's long-term interests. ${ }^{8}$ One advocate of rehabilitation, not retribution, was the veteran socialist politician and former (and future) French prime minister, Léon Blum. He had survived three years in a succession of Vichy prisons, and two years in Buchenwald and Dachau, before being rescued by American troops, days before the end of the war, and returned to Paris. ${ }^{-}$Even while a prisoner in Buchenwald he rejected collective responsibility and, unlike Vermeil, insisted on the need to distinguish between German leaders and the population they had led. ${ }^{10}$ His and his family's fate (his son was an imprisoned army officer and his brother died in Auschwitz), and his stature as one of the few French leaders untarnished by association with the Vichy regime, ${ }^{11}$ gave him particular authority.

Blum helped to write the French Socialist Party's (Section Française de l'Internationale Ouvrière, SFIO) first post-war statement on Germany. It said that the country had to be occupied and disarmed, its industry internationally controlled, its landed property divided up, its war criminals punished, and its education system transformed. But there was hope that 'one day the German democratic elements and the working classes will themselves create a humane and pacific German nation'. The party wanted 'to call the attention of the country to the dangers of nationalist revenge which asks for the dismemberment of Germany and the annexation of specifically German territory'. ${ }^{12}$ Instead of annexation, they proposed an international administration of the Ruhr and the Rhineland by the Big Four, until the United Nations could appoint a permanent body. Industrial profits would fund the reconstruction of those countries devastated by occupation and war, and a small portion would be used for Germany to meet its basic needs, so the Allies would not have to pay. Using continued German production, they argued, was a more effective and viable alternative to proposals such as the Morgenthau Plan, which called for radical deindustrialization. ${ }^{13}$

Germany would have to be 'detoxified' and reformed, and permanently integrated into a new, stable European framework (by force if necessary), rigorous enough to prevent any future German war. European federalism was 'the beginning of hope and an instrument of peace', and essential to French security. 'We must make Europe,' Blum wrote; 'We must make it with Germany and not for her.' ${ }^{14}$ For this project, French domestic policy had to be joined up with its foreign policy: French reconstruction had to be proceed together with that of Germany; social and economic reforms in France had to be matched by similar reforms in the occupation zones and elsewhere to build the basis for a socialist European federation which could readmit Germany into the community of nations. The emphasis on Europe also featured in proposals put forward by politicians such as the radical René Mayer, a future president of the European Coal and Steel Community. Mayer argued that French economic needs and collective security could best be guaranteed in the context of a new European federation. 15

The French Left had no monopoly on plans for a reorganization of Europe, but by 1945 it had shaped these discussions to a significant degree. After their split with de Gaulle, the Christian Democrats provided some guiding ideas for European integration, and were to eventually put may of them into practice. ${ }^{16}$ But in 1945 , still led by de Gaulle, many on the anti-Vichy French Right-among them the future architects of Western European integration, Jean Monnet and Robert Schuman — still focused on France's place in the world without giving much thought to the wider European framework. In their plans the occupation of Germany was above all a means for French reconstruction. ${ }^{17}$ This was a crucial difference in the frantic months after the war when occupation policy was being formulated. Where de Gaulle and his allies thought about Europe-wide mechanisms to enable France to control and exploit Germany's economic potential, many socialists and radicals focused on a reform and re-education of Germany as part of a wider European solution. Only during Robert Schuman's time as prime minister in 1947-8, in discussions with and under pressure from the Americans, did European integration become the policy of the leading faction of the French Right, which reflected a realization that the national plan for unilateral reconstruction had failed. ${ }^{18}$ But that is jumping ahead of the story. 
In 1945, the first of the two main strands of thought in the French military government was the conservative, militarist approach of de Gaulle, incorporating aspects of Vermeil's assessments of the German character, and led on the ground by by Pierre-Marie Koenig. The second, more socialist position, drawing on different components of Vermeil's conclusions, was led in the zone by Émile Laffon. A lawyer and engineer by training, Laffon was a rising star of the FFI and the Resistance. He had been a captain in the Free French Air Force, and from June 1943 until 1944 commissioner of the interior in Algiers. Later as a representative of the French Committee of National Liberation (Comité Français de Libération Nationale, CFLN, which became the provisional government after the Normandy landings), Laffon oversaw the organization of the Resistance. ${ }^{19}$ He was regularly parachuted into occupied France as a liaison between London and France. ${ }^{20}$ In April 1944 he became commissioner in charge of civil affairs, and four months later, on the day of the liberation of Paris, took office as secretary general of the Ministry of the Interior. A year later he was appointed administrateur général in Germany, the highest civilian job in the French occupation. Like Vermeil and Blum, he opposed a dismemberment of Germany and annexation of German territory by France. Instead, he argued that a systematic development of the zone's economy in its entirety was preferable to annexing the Saar, Ruhr, and Rhineland. Laffon was not a member of the Socialist Party, but his position was close to that of leading socialists, and he filled his staff in Baden-Baden with young members from the Resistance, many of whom were socialists. ${ }^{21}$ Many of his staff shared a missionary mindset, and saw the occupation as a vehicle for wider reforms, and France as a role model for the entire continent. A new beginning, they argued, could only be achieved in cooperation with the Germans. ${ }^{22}$

The frequent clashes between Koenig and Laffon exemplified very different approaches to the occupation. They partly stemmed from the fact that France was in upheaval in a way that the other occupiers were not. Both the United States and Britain saw changes of government at the end of the war (Roosevelt died in April, and Churchill lost the general election in July) - and this change of Anglo-American leaders was held responsible for Stalin obtaining a number of Soviet demands in the face of American or British opposition. The Fourth French Republic saw twenty-six governments come and go between 1944 and $1958 .^{23}$ Even if there was considerable continuity in the 'French thesis' on Germany, ${ }^{24}$ the changing governments represented significant fissures within the French political establishment, which slowed and hampered preparations for the occupation.

Many battles were fought in the French press, which eagerly reported the faults and shortcomings of the occupation. Left-wing groups attacked the army, and later the French military government in Germany, for having too few members of the Resistance, and for harming French interests with pro-German or pro-Vichy policies. An accusation aired repeatedly was that the French occupation army was a refuge for collaborators avoiding punishment at home. The communists claimed that Vichyites had created a 'Little Vichy' in Germany, a claim in fact confirmed when a Commission of Inquiry in April 1946 found that thirteen of the zone's highest officials were implicated in the Vichy regime, and recommended their dismissal. ${ }^{25}$ Even before the occupation began, clashes between different factionsGaullists and socialists, doves and hawks, military and civilians, pro- and anti-Americans - mirrored those taking place in the Paris ministries and across France, and frequently limited any one group's room for manoeuvre. Hardly any of these proclamations made any direct reference to public health provisions among the occupied population. But these fault lines shaped the possibilities for public health work, and often became visible only when the French teams encountered their first health panics in the zone.

The French occupation of Germany had a difficult set of starting conditions. Political divisions were exacerbated by the institutional chaos. In Paris the acronym-littered landscape was initially dominated by the Interministerial Committee for German and Austrian Affairs (Comité Interministériel des Affaires Allemandes et Autrichiennes, CIAAA), which began to prepare and issue directives shortly after its creation in July 1944. Its General Secretariat (Sécretariat Général aux Affaires Allemandes et Autrichiennes, SGAAA) consisted of representatives from six different ministries, who attempted to coordinate their different interests and those of commanders in Germany and Austria. This authority for the occupied territories was reformed, renamed, and repopulated several times over subsequent months. Less than a year into the occupation, the CIAAA was expanded by two further ministries and became the Commissariat for German and Austrian Affairs (Commissariat Général aux Affaires Allemandes et Autrichiennes, CGAAA), headed by René Mayer, before being dissolved after the departure of de Gaulle from the political scene in March 1946. Other, generally short-lived offices appeared in its place, such as the State Secretariat for German and Austrian Affairs (Sécrétariat d'État aux Affaires Allemandes et Autrichiennes, SEAAA), created in November 1947, but already dissolved by summer $1948 .{ }^{26}$ These bodies were a fertile environment for power struggles and competition. 
France had a zone that made little structural, political, or economic sense. The French occupation territory was created out of areas formerly allocated to the British and American zones. The Americans retained key cities such as Stuttgart, and key infrastructures such as the motorway between Karlsruhe, Stuttgart, and Munich. The French area contained several Länder whose capitals were outside the zone (Karlsruhe in Baden, Stuttgart in Württemberg, and Cologne in the Rhineland). Only one city, Ludwigshafen, had more than 100,000 inhabitants. Despite being the most rural zone, it was far from self-sufficient. ${ }^{27}$ French leaders, aware of these shortcomings, periodically attempted to revise the boundaries. In March 1945, de Gaulle urged his commanders to trump the Americans by arriving first in the south-western territories. Successful in the ensuing race, de Gaulle then refused to hand over Stuttgart to the Americans. This battle ended in a political debacle: French troops were forced to clear out of the city, and FrenchAmerican relations barely had time to recover before discussions in the ACC caused more serious and permanent disagreements.

The French authorities also had a serious time problem. General de Lattre de Tassigny and the First French Army crossed the Rhine only seven months after the liberation of Paris. One of the few guides available to French personnel was the SHAEF Handbook for Military Government in Germany — but only in English, until a French translation was published in March $1945 .^{28}$ Concrete French directives on occupation policy only appeared months after they had begun their occupation duties: the CIAAA issued its first instructions to General Koenig in late July 1945. These stated that the primary aim of the occupation was security, to be achieved through a three-pronged approach — control of the German economy, decentralization of political structures, and lasting democratization and denazification of German cultural life. ${ }^{29}$

Not only did these instructions come very late, they also contained significant ambiguities. In part to preserve French leaders' room for manoeuvre (and therefore leaving many issues untouched), they failed to resolve or even identify some fundamental contradictions: French economic priorities favoured a unified administration of Germany, but French political and security strategies favoured decentralization, if not dismemberment. ${ }^{30}$ Different military government departments found themselves pitted against each other, and many officers were unbriefed or bewildered. Henri Humblot remembered that he had taken courses with the French military administration, but, before coming to Germany in 1945 as a young communist and an agrégé d'allemand fresh from university, he had no administrative experience, no instructions or guidelines, and no idea about his new responsibilities as an officer in charge of reeducation and sport. 31

French troops therefore drew heavily on SHAEF's guides, particularly in specialist or technical fields. Denazification instructions matched those issued in the other zones: the priority was to arrest war criminals and NSDAP functionaries, on the basis of existing lists. All active Nazis were to be removed from public office and to be replaced with acceptable German appointments. If no tolerable German replacements could be found, military government would have to take on those tasks in the interim. ${ }^{32}$ This was not quite what the French's own diagnoses of Nazism had prescribed. Taking the recommendations of Vermeil and others at their word, commentators and historians have argued that French attitudes towards denazification were more straightforward than those of the other occupiers. F. Roy Willis wrote that they were 'not hampered ... by the need to distinguish between good and bad Germans, since they believed all Germans to be more or less under the influence of Nazism, and more especially of aggressive and militaristic nationalism'. ${ }^{33}$ But although French analyses on key questions differed from those of the other occupiers, France's late start meant that it was bound - for both practical and political reasons - by Anglo-American policies, and forced to rely on SHAEF preparations.

Public health was no exception. By the time French participation was agreed, SHAEF's G5 Division had already produced guidelines on the mission, policy, timing, and general premises of public health work, which were issued unchanged to the French teams. ${ }^{34}$ Instructions to AMFA's (Corps d'Administration Militaire Française en Allemagne) Health Section (Section Santé) thus shared the premises of health work elsewhere. 35

A French translation of chapter 6 of SHAEF's Handbook for Military Government thus explained the premises of health work in occupied Germany to AMFA's health personnel. ${ }^{36}$ The main function of public health officers was to control infectious diseases and to prevent their spread across German borders - a task which required, it noted, functioning local health agencies. German health offices would continue to operate while active Nazis and Nazi sympathizers were removed and replaced by 'acceptable personnel'. Captured military stocks and local supplies had to be utilized to meet the urgent needs of the Allies; additional stocks would only be provided to prevent health problems from interfering with military operations, and only for the protection of UN nationals and Allied troops. 
But, this chapter stated, military government officers were likely to confront severe health problems among the German population. These arose directly out of problems such as the overpopulation of many cities, camps, and shelters; the destruction of the sewage system and other public health installations; the spread of infections by population movements; and widespread malnourishment, demoralization, and nervous disorders. Typhus, typhoid, diphtheria, dysentery, scarlet fever, and venereal diseases, among others, would become pressing concerns, and essential medical supplies and equipment to tackle them were likely to be in short supply. ${ }^{37}$

French health officers also studied the relevant excerpts from the Civil Affairs Handbook on Germany. ${ }^{38}$ This, and the Technical Manual for Public Health Officers, could not give solutions to all the health problems they were going to encounter, explained Lieutenant General A. E. Grasett from SHAEF's G5 Division to his French staff, but they could provide starting points. ${ }^{39}$ Other preparatory material available to AMFA's Health Section included lists of health departments in south-western Germany, and charts depicting the organization of the German health service. At least some of this material was prepared by the Americans, before the French zone was carved out of the American and British zones. ${ }^{40}$

French health teams came equipped with the same set of inconsistencies and paradoxes as their colleagues in the other zones. Public health protection was identified as a crucial element of military success, but Allied input — both of personnel and supplies - was strictly limited. Military government public health functions were to be restricted to urgent epidemic work, but at the same time health was to be recognized as 'closely interlaced with many other military functions'. ${ }^{41}$ Conditions were likely to be poor, and could threaten Allied troops and neighbouring populations, but Germans were to shoulder the burden of health work. Conscription and casualties had reduced numbers of qualified medical personnel, but a purge of 'active Nazis, ardent Nazi sympathisers, Nazi agencies and ideologies' was deemed vitally necessary. Although the threat of epidemics demanded the centralized collection of data and coordinated anti-epidemic measures, a centralization of the health system was deemed undesirable, and the local health office (Gesundheitsamt) was to be the main pillar of the health administration.

The French Public Health Directorate seemed well aware of German doctors' widespread support for Nazism. Books and pamphlets by leading Nazis such as Leonardo Conti, the Third Reich's health minister (Reichsgesundheitsführer), and the eugenicists Eugen Fischer and Otmar von Verschuer, had been translated into French during the Vichy years. ${ }^{42}$ The Health Directorate also collected a range of German publications on eugenics and hereditary biology, as well as reports on organizational changes in the health service since the end of the First World War. ${ }^{43}$ A number of background studies explained that the Nazi regime had many loyal and vociferous supporters among the medical profession. A paper entitled 'The German Doctor' observed that the medical profession not only shared the characteristics of the German bourgeoisie at large which had enabled the rise of Nazism (such as strong nationalism and the 'conviction that everybody was envious of Germany and wanted to destroy it'), but many had particularly supported the Nazis' racial and eugenic ambitions. ${ }^{44}$ Doctors had joined the NSDAP even before 1933, the paper noted, and were rewarded by the restriction of non-Aryan doctors, which helped their advancement. The Nazis had 'found in the medical corps a devoted tool for the execution of all party orders'. Doctors had not protested against the treatment of the populations occupied by Germany, nor against worsening work conditions in their own country, which had 'profoundly influenced the health of the German people'. Some doctors had committed war crimes, including those who conducted medical experiments on concentration camp inmates. ${ }^{45}$

But although this and other reports outlined how the German health service had been changed, compromised, and damaged by Nazi ideology, it also suggested that it was not beyond redemption. Implicit in its recommendations was the belief that if the structural and ideological changes since 1933 were annulled and reversed, a sound health service could flourish once again. The Office for Public Health (Amt für Volksgesundheit) had been created as a Nazi propaganda organ to complement the work of the local health office (Gesundheitsamt); dissolving the former would allow the latter to resume its full responsibilities. ${ }^{46}$ In this conclusion French health officers diverged from the analyses of Vermeil, Joseph Rovan (more about him later), and other French experts on Germany, who identified a century of continuous German militarism, expansionism, and national psychological shortcomings. AMFA's medical officers, by contrast, did not treat the health system as the latest manifestation of long-standing, harmful German traits. Rather, they thought the transformations since 1933 could be peeled back to reveal sound professional principles. This was an important distinction which caused tension with other military governments' departmentswhich mirrored divisions between health teams and other personnel in the other occupation zones. 
French troops thus shared many of the other occupiers' problems. Tensions between military and civilian agendas, gaps between plans and realities, a need for flexibility coupled with an absence of clear instructions, and a paradoxical location of public health in the occupation programme all presented the occupiers with impossible choices. But in addition, French preparations for their occupation of Germany were also shaped by contradictions not quite shared by the other occupiers: their staffs had to rely on Anglo-American preparations even where they seemed to run counter to French analyses, interests, and policies. Moreover, the French occupation project had to accommodate contradictory directions for future French reconstruction, such as a simultaneous demand for both centralization and radical decentralization. It was not going to be an easy job.

\section{Compromises}

First contacts between occupiers and occupied were full of inconsistencies. Negative first impressions, fuelled by violence, brutality, and misunderstandings, dominated contemporary accounts. French commanders, like their Soviet counterparts, found it difficult to keep their troops in check. French soldiers and members of the Resistance, many of whom had suffered personally (and knew many others people who had), now 'took pleasure in seeing the Germans scatter in terror at the sight of the French army'. 47 In his 1955 history of the Vichy Regime Aron wrote that the Resistance had 'consisted not only of heroes, of acts of the highest morality, the greatest courage and purest patriotism. There existed among them disreputable people, black sheep who disfigured organisations which were based on faith and ideals.' It was clear that 'under cover of the Resistance, acts of banditry were committed. There were thefts of jewelry, public and private funds, and sometimes a paying off of old scores which had nothing whatever to do with politics. ${ }^{48}$ His observation also holds true for the French occupation troops.

Violence was not just the result of a breakdown of army discipline, but was occasionally encouraged by semi-official instructions or individual commanders' condoning of misconduct. As in the British and American zones, the French armies' manuals had painted a stark and unreal picture of Germans. AMFA's first information bulletin in March 1945 advised French officers to be wary of German sadomasochistic personality traits: '[E]very manifestation of strength' was 'agreeable to him [the German] in his deepest character', it warned, and urged officers not to 'forget that the German is, in his inner nature, sensitive only to force. Every manifestation of force is deeply pleasing to him. '49 Many French soldiers discovered that this advice proved ultimately futile in the execution of their daily tasks.

French troops' relations with the German population were not helpted by Jean de Lattre de Tassigny's approach to life in the zone. The area around Lake Constance, relatively unsullied by war, complemented his ambitions. His staff occupied luxurious villas, organized showy parades, and feasted on enormous banquets. He encouraged his officers to bring their families, and to set up rest camps and sanatoria for French deportees. Thousands of French children spent their summer holidays in the Black Forest. ${ }^{50} \mathrm{He}$ was quickly accused of ruling with all the ceremonies of an 'imperial viceroy'. ${ }^{51}$ Le Monde's military correspondent, Jean Planchais, observed that under de Lattre's rule officers 'got into the habit of enjoying a high standard of living, and on returning to the circumscribed living conditions in France itself, they felt the change more painfully and deeply for being, in their eyes, the victims of ingratitude'. ${ }^{2}$ De Lattre's approach provoked bitter resentment from local Germans and fierce criticism from French observers.

While some commanders acted out their imperial ambitions, others were more measured. In August 1945 General de Beauchesne promised Berliners in the French sector that the French would provide the population with as much aid as possible. It would maintain order and act 'in fullest fairness'. France had to remember French suffering of the previous years, he declared; they could not forget the 175,000 hostages shot on French soil, the burnt-down villages, the massacres of French citizens, or the deaths of 200,000 French deportees in concentration camps. But, he went on, France was magnanimous and sought no revenge. The French military government would only demand strict discipline and cooperation from the Germans to show that they had put a final end to Nazi crimes and methods. $\frac{53}{3}$

Similar sentiments were aired by General de Gaulle during his first visit in autumn 1945. He said that France would not seek revenge, insist on collective responsibility, or even press for severe measures. Instead, the military government's own newspaper reported, he wanted to inaugurate a different tone - new to both French and Germansof conciliation, and to continue France's historical mission to spread enlightenment. ${ }^{54}$ In its occupation of Germany, de Gaulle proclaimed, France would 'obey the sort of historical vocation' which it had carried in the past. Even if France had to take possession of German territory in the Ruhr - which, he explained, was a 'guarantee' for both Western European security and French reconstruction-French policy would be measured and forward-looking. German cities would require and receive French material assistance, and the French occupation would help the 'states of the Rhineland' to find their 'western spirit', and 'abandon the idea of a Germany grouped around the now 
destroyed Prussia, in order to turn towards the horizon, which will give them more hope towards Western Europe, and above all towards France'. 55

These early proclamations contained indications about longer-term French aims and ambitions in Germany. Joseph Rovan, the politician, scholar, and influential expert on Germany, argued that the French now had to 'help [the Germans] to become themselves again'. ${ }^{56}$ Rovan, a student of Vermeil's, was himself of German origin. Born in 1918 in Munich to Jews who had converted to Protestantism, he converted to Catholicism and emigrated to France in 1934. He later joined the Resistance, and the Gestapo arrested him in February 1944 and sent him to Dachau, where he befriended Edmond Michelet, future minister in de Gaulle's post-war government, whose staff he initially joined as a political adviser. ${ }^{57}$ In a much-quoted article in L'Esprit in October 1945, Rovan argued that France's occupation had to achieve both a renewal of, and reconciliation with, Germany. Germans had to be reacquainted with their own humanist tradition - Goethe, Kant, and Beethoven. Above all, the French had to inculcate in them something the French possessed but the Germans lacked: an appreciation of the 'dignity of man' and 'that universalism which is the vocation of the French spirit'. 'Le grande nation' had to teach others the meaning of liberty. ${ }^{58}$ As an officer at the Directorate for Public Education at Baden-Baden, Rovan set out to shape French occupation and re-education policy in these terms. These ideas distinguished the French occupation project from the other Western Allies. Where particularly the British, and even the Americans, found it difficult to explain their longer-term purpose in Germany, beyond the activities surrounding the four Ds (demilitarization, deindustrialization, denazification, decartelization), the French, like some of the Soviets, had a clearer sense of their long-term objectives. This did not increase the popularity of France or the Soviet Union, but in both cases it removed some of the uncertainties about the purpose of the occupation.

The French occupation began to take shape in the early summer of 1945. The other three military governments were already more or less set up. General Pierre-Marie Koenig became commander-in-chief (Commandement en Chef Français en Allemagne, CCFA) in June 1945, reporting to de Gaulle in Paris. A month later French troops moved into Berlin and took up the French part of the ACC, but this office was only loosely connected to the zone and also reported directly to Paris. In August 1945, Émile Laffon became administrator of the Military Government of the French Zone of Occupation (Gouvernement Militaire de La Zone Française d'Occupation, GMZFO), and moved into the new headquarters in the town of Baden-Baden. Laffon's organization, also responsible to Paris, was divided into four directorates: administrative affairs (which included public health); economics and finance; justice and law; and public safety and security. This structure was replicated at the regional level, which involved considerable duplication and confusion about responsibilities. Regional military governments (known as délégations supérieures) were set up for each of the four Länder, with headquarters in Koblenz, Saarbrücken, Tübingen, and Freiburg, and headed by a governor (known as délégué supérieur). The military occupation teams continued to exist at all levels, side by side with, but independent from, the civil administration. 59

The various local and regional military government offices and their channels of communication with headquarters were slow to emerge. Partly this reflected a lack of policy directives, which meant that officers everywhere had to improvise. When asked later about what instructions he had been given, Roger Humbert, an economist based in Berlin, just laughed. ${ }^{60}$ Even when officers in Baden-Baden worked out more detailed guidelines and policies, they could not be sure that they actually reached the relevant local officers, let alone that the officers took any notice of them. .61

Partly this was also a structural problem. Joseph Rovan remembered that the French set-up was one of 'total confusion'. ${ }^{62}$ The origins of this confusion lay directly in the push and pull of the contradictory tendencies of centralization and decentralization. French politicians sought to destroy the political unity of Germany, and opposed any centralization. But French economic interests, and the effective management of a defeated and devastated country, required centralized decision-making for the zone and coordination with the other zones. De Gaulle and his staff initially opted to follow political interests, just as the reality of administrative work in Germany supported the direct opposite. Moreover, the French occupation machinery was deliberately decentralized, just when practical problems required it to be centrally coordinated. 63

French officials working on cultural and educational policy often welcomed the absence of control, which allowed them to develop their own initiatives, more or less free from restriction. Henri Humblot remembered that there were significant differences between the regional military governments, and a 'curious mosaic' of ideas, programmes, initiatives, and personalities within each office. Because of the lack of central instructions, occupation policy could 
develop from the ground upwards, and was, as a result, particularly suited to local conditions and problems. ${ }^{64}$ But to health officers this only created more problems. Many public health measures would be effective only if applied throughout the zone. Disease data and vital statistics had to be collected centrally, and drugs and medical supplies agreed by the authorities in Paris had to be distributed on the basis of a centrally agreed formula. Like the Directorate of Economy and Finance, public health staffs complained about the reality of decentralization, which made their work so much harder. 65

The French zone's health authorities were built as haphazardly as the rest of the military government. Delays at the beginning were caused by the First French Army's G5 Division's slow handover to the GMZFO's Public Health Directorate. Public health officers in the southern parts of the zone had begun to set up provincial authorities in spring 1945, but their efforts were nullified by the handover of Karlsruhe and Stuttgart to the Americans. Areas in the north of the zone were not fully occupied until July 1945. ${ }^{66}$ By September 1945 the Public Health Directorate in BadenBaden had seventeen officers: some came from the military, but most from ASTO (Assimilés Spéciaux pour les Territoires Occupés). 67

One of the civilian appointments was Frédéric Falkenburger. Born in Berlin in 1890, he studied medicine at the University of Strasbourg before the First World War. Afterwards he worked at a venereal disease clinic, then at a local health insurance body in Berlin, before emigrating to Paris in 1933. He was naturalized in 1937 (after a brief period in Moscow), and became 'Frédéric'. Like Joseph Rovan, who made a similar journey, he made influential contacts in Paris and later within the Resistance. He worked for the Centre National de la Recherche Scientifique (CNRS), and then as an anthropologist at the Musée de l'Homme in Paris, where his colleagues included Paul Rivet (an eminent anthropologist and the French delegate at the founding meeting of UNESCO), and Jacques Soustelle (a minister under de Gaulle, later general secretary of the Gaullist party, Rassemblement du Peuple Français (RPF), and governor general of Algeria). ${ }^{68}$ Falkenburger was deprived of his French citizenship in 1940, arrested in 1942, and interned in Gurs in the Pyrenees. His son thought that only his medical skills saved him from deportation. He escaped, joined the Resistance, and lived illegally until the liberation of France in June 1944. It seems that he converted to Catholicism after divorcing his Jewish wife and marrying a Roman Catholic. $\frac{69}{}$

Falkenburger offered his services to the French occupation staff, while still under the command of General LouisMarie Koelz, and based at the Hôtel de l'Europe in Paris. An old colleague, Jacques Soustelle, just appointed minister for the colonies in de Gaulle's provisional government, recommended Falkenburger to General Koelz, who called him in for an interview. The two men noted that they had fought at the same locations during the First World War, on opposite sides. Shortly afterwards, Falkenburger received two letters: a rejection from the Hôtel de l'Europe; and personal note from General Koelz, appointing him to the rank of médecin lieutenant-colonel at the Health Directorate in Baden-Baden, under the command of Inspector General Charles Coulon. He worked there for four years, before becoming head of the health service of the French high commissioner in Germany. ${ }^{70}$ Individuals' careers in the French apparatus were often shaped by personal connections and character references from influential people. Falkenburger's acceptability was helped by the fact that he had been educated in France, was bilingual, and fully naturalized. In 1946 he arranged a job for his son, Paul Falkenburger, as a public education officer in Freiburg. Later, Paul Falkenburger was General de Gaulle's and Georges Pompidou's interpreter at meetings with Konrad Adenauer and Helmut Kohl. ${ }^{71}$

The French zone had suffered considerably less war damage than the others, particularly the Soviet and British zones. An article in The Times observed, almost jealously, that the French had been lucky: they had a small area, largely rural, with only a handful of towns, and, by German standards, little physical destruction. In addition, only a small proportion of the great flood of German expellees from the east headed there. ${ }^{72}$ But the French territory, too, was marred by chaos and disruption, particularly in the north. In 1952 the French economist André Piettre published a study of post-war Germany, in which he contrasted the demographic and economic conditions encountered by the four occupying powers. Citing German data, he noted that towns with more than 100,000 inhabitants, had been hit proportionately harder in the French zone: in such towns in the Soviet zone only 23 per cent, and in the British and American zones 33 per cent, of buildings, had been completely destroyed, but in the French zone it was 44 per cent. Only 11 per cent of buildings remained intact in these larger French towns, compared to 39 per cent in the Soviet zone, 21 per cent in the British, and 19 per cent in the American zone. ${ }^{73}$ An American report agreed that the French zone's cities—Friedrichshafen, Freiburg, Saarbrucken, Koblenz, Mainz-had been destroyed to around 50 per cent. ${ }^{74}$ The French zone had few large towns, and none comparable in size to cities such as Frankfurt and Dresden, but this still represented considerable damage to buildings, sanitary installations, and infrastructures. 
French troops noticed that conditions changed radically as they crossed to the eastern bank of the Rhine. The cities near the targets of the Allied bombs were eerily empty, while undamaged towns and villages nearby overflowed with people seeking shelter. When the French authorities began to take population censuses in spring 1945, Baden-Baden contained 15,000 refugees, and Konstanz's population of 70,000 was double its normal size. ${ }^{75}$ Many German officials had abandoned their posts. In the First French Army area, all the members of the state administration and all but a few of the Landräte had fled, and at least 30 per cent of mayors had disappeared. ${ }^{76}$ This mess was not cleared up in a hurry. In the autumn of 1946 Carl Welty, an ornithologist from Indiana, led a Quaker relief team in the French zone, and thought that conditions were still dire. Coming from Luxembourg, where '[a] genteel air of prosperity pervaded the whole place', he was immediately struck by the 'terrific contrast the minute we crossed into Germany!" 77 His first destination was the city of Koblenz (one of 'the avenues of Nazism', according to de Gaulle ${ }^{78}$ ): 'even after dark [it] turns your stomach. It is a terrific desolation of gutted architecture.' By then the main streets had been cleared of rubble, but it was rare to see 'a building damaged slightly enough that a family can live in it ... People simply pile enough rocks in the windows and doors to make a wall, and then shovel the rest of the rubble inside the burned-out building.' The city looked 'so sick that one doubts its recovery', and reconstruction would be 'a monumental job, taking years and years at the present slow rate'. ${ }^{79}$

Towns like Koblenz were in a grim state, but the most shocking reports came from French officers in Berlin. The French sector of the city, like the zone, had been carved out of parts initially allocated to the British and Americans. Renée Bédarida, a young French women fresh out of the Resistance, worked as an ASTO officer for the ACC in Berlin. In a letter she described the 'hallucinative spectacle' of a 'city of death': 'not a street remains intact', she wrote, 'all houses are gutted, isolated façades. Women of the NSDAP collect the intact stones one by one. Passersby are used to this spectacle as if they were in a normal city. They are dirty, badly dressed, and always loaded with a sack of potatoes or a bundle of dead branches.' Berliners lived crammed in cellars or barely habitable rooms. She wrote that underground tunnels and rivers were littered with corpses, and their nauseating smell pervaded everything. ${ }^{80}$ Roger Humbert recalled that when he arrived in Berlin in 1945 to join the French Directorate of Economy and Finance, there was nothing there. 'We had to be the government of Germany', he said, a job made all the more difficult by the problems caused by refugees and displaced persons. 81

French health teams were as concerned about epidemics and public health disasters as those in the other zones. Given their zone's close proximity to France, these concerns were heightened when, in March 1945, the first cases of typhus were verified west of the Rhine. The US Army, together with SHAEF, set up a cordon sanitaire along the Rhine from the Netherlands to the Swiss border: civilians were prohibited from crossing without first submitting to an examination and DDT dusting. Those from prisons, concentration camps, refugee camps, and assembly points were 'dusted' en masse. ${ }^{82}$ General Coulon from the Public Health Directorate urged his superiors to grant funds for an increased production of DDT and typhus vaccine, and to initiate the compulsory vaccination of all military government personnel. ${ }^{83}$ In the end, the cordon sanitaire and accompanying measures were deemed a success. 'While we had reason to fear the outbreak of a typhus epidemic', noted a retrospective of the French Military Government's Directorate of Public Health in 1949, 'in fact, we had no epidemic of any kind. We only recorded two secondary cases [of typhus] apart from the fifty-odd cases brought into the zone by refugees from Central Europe and from other zones of Germany'; by 1946 no new typhus cases were recorded. ${ }^{84}$ But that is jumping ahead of the story; in the months after the war the threat of a typhus epidemic was still a great concern.

French health officers were also alarmed by rising rates of venereal diseases. In August 1945, a note from General Melnotte, director of the French troops' health service, told Coulon that the problem had become urgent. The health of troops in Germany was 'gravely compromised' by sexually transmitted infections, he wrote, caused mostly by soldiers' contacts with German women. It was 'absolutely essential and urgent to impose rigorous preventive measures, even if they are brutal'. ${ }^{85}$ Like the other occupiers, the French authorities attempted to limit venereal diseases with a battery of measures: raids on public venues, control of prostitution, compulsory examination of suspects, issuance of registration cards which declared infection, and compulsory reporting of all cases of syphilis and gonorrhoea by the local German health offices. ${ }^{86}$ In late August 1945 Émile Laffon yielded to the Public Health Directorate's advice and authorized the compulsory hospitalization of German women who infected members of the French military. ${ }^{87}$ Similar measures were in use in the other zones.

All in all, the French zone had a similar range of infectious diseases and public health concerns as elsewhere. First reports from Berlin's health officials to their French superiors noted an alarmingly high rate of dysentery in the French sector, particularly in the inner-city district of Wedding. The situation had been made worse because not nearly 
enough drugs and medical supplies were available to limit the spread. Hospitals were forced to send away all but the most acute of the infectious cases. ${ }^{88}$ Other towns also complained about broken water and sewage pipes and other components of the sanitary infrastructure. Freiburg's centre, reduced to rubble by an RAF bombing raid in November 1944, had all the ingredients for a health crisis. When the French troops arrived, over 1,200 corpses were reported to be still buried under the rubble. ${ }^{89}$ With rising temperatures and groundwater they threatened to pollute the city's entire water supply. The French instructed the city's university medical faculty to survey the health situation. They identified, apart from problems such as the destruction of buildings, pipes, hospitals, and laboratories, one particular area of concern: food shortages. Since the end of the war official daily rations had decreased from 1,759 to just 586 calories per person per day. ${ }^{90}$ Some commentators have since directly attributed the rising mortality rates to food shortages; the historian Eduard Seidler has calculated that infant mortality rates in Freiburg were over 30 per cent in spring 1946. ${ }^{91}$ Concerns about imminent starvation were reinforced by reports from nearby towns, whose food supplies had more or less run out. Although shortages could be alleviated with surpluses from adjacent rural areas, the lack of transport and military security regulations often made this impossible. ${ }^{92}$

Despite these problems, comparatively speaking, physical and demographic conditions were more favourable than those in the rest of Germany. Most communities east of the Rhine, one report stated, had at least an embryonic health organization of a doctor and several registered nurses or midwives. ${ }^{93}$ German mortality in the zone was lower than mortality in France itself. ${ }^{94}$ Major infectious disease incidence rates were persistently lowest or second-lowest in the French zone (and consistently highest in the Soviet zone). ${ }^{95}$ Even in Berlin, problems were comparatively less severe in the French sector. Because it was much smaller than the other three, both in area and population, the French authorities also had to deal with a smaller share of the overall burden. The two French districts had to accommodate and feed by far the smallest share of newly arriving German refugees: by November 1945 fewer than 2,000 refugees lived in the French sector, compared with almost 6,000 in the American, almost 9,000 in the British, and over 10,000 in the Soviet sector. ${ }^{96}$ Since, as report after report pointed out, refugees were directly associated with escalating disease and mortality rates, the French sector was exposed to fewer problems, and only spent a fraction of its budgets on refugee health costs. ${ }^{97}$

Comparisons of physical conditions indicate that the immediate public health challenges were less severe in the French zone, but they do not take into account the material, political, or conceptual resources at the disposal of public health officers. Health work everywhere in Germany was shaped by shortages, but they were of different scales, and dealt with differently, in each occupation zone. In the French zone confrontations over supply shortages plagued the relationship between the occupation authorities, and the German doctors and general population, for years. At the same time, personnel shortages were negotiated by a series of modifications to initial plans and directives.

As far as medical personnel was concerned, health teams argued that initial staffing allocations had underestimated requirements. This was despite the fact that the density of military government personnel was highest of all in the French zone, since the policy of decentralization required personnel for all technical fields at even the local level. The Times reported in December 1946 (after demobilization had begun to reduce the size of all four military governments) that the French had a density of 18 French officials to every 10,000 Germans; the British had a density of 10; and the Americans of only 3 officials in their respective zones. The French authorities delegated fewer responsibilities to the Germans than the other occupiers, and German authorities had fewer powers than their counterparts in the other zones. ${ }^{98}$ Demobilization directly contradicted the idea that the Germans ought not to be given political and administrative responsibilities until they had learnt the lessons of history, and the assumption that the occupation would be a long project. But because of financial pressure from Paris, demobilization began early in the French zone and proceeded quickly - from around 300,000 in autumn 1945, to 200,000 in January 1946, 75,000 in May 1947, and only 53,000 soldiers in May 1948. ${ }^{99}$ Public health staff, like their counterparts elsewhere, were united in their insistence that there were simply not enough people available for urgent public health work, and not even all jobs in the Health Directorate could be filled. ${ }^{100}$ Budget cuts and reductions in the overall size of the French occupation forces only caused further panic. ${ }^{101}$

Demobilization brought into sharp focus the lack of qualified, and politically acceptable, German medical personnel. Already before the end of the war, a French report had identified severe personnel shortages in the German health service, exacerbated, it noted, by restrictions on non-Aryans' right to practise medicine and the drafting of many doctors into the army. Many old and retired individuals had been used during the war: in 1943, over 300 practising German doctors were older than 80 years, and 3,000 were older than 70 years of age, but many of them would not be able to continue for much longer. ${ }^{102}$ After the occupation began, the German health offices also warned about 
shortages. The health authorities in Berlin pointed out that the ratio of German doctors to inhabitants was persistently most unfavourable in the French sector: in the autumn of 1945 the British sector had 1.75 doctors per 1,000 inhabitants, and the American sector 1.16; but only 0.71 doctors per 1,000 inhabitants were available in the Soviet sector, and only 0.67 in the French sector. ${ }^{103}$ This uneven distribution of doctors in Berlin-which mirrored the uneven distribution of doctors across Germany - continued to plague the French (and Soviet) health authorities for some time. By November 1946, the French districts were still short of medical personnel. The Berlin health office calculated a minimum need of 8 doctors per 10,000 inhabitants, and lamented the unbalanced distribution: the Soviet sector had a shortage of 358 doctors, and the French a shortage of 119. At the same time, the American sector had an excess of 156 , and the British an excess of $321 .{ }^{104}$

Such personnel shortages, when fears about epidemic crises were at their most acute, led to a series of compromises, above all in denazification. In the British, American, and even Soviet zones, these compromises involved a recognition of the irreconcilable gaps between what had been planned and what now seemed feasible. As a result, the far-reaching ambitions for a wholesale cleansing of German society were abandoned, and formerly active, influential, and loyal members of the NSDAP were recruited to work in the health service, if the occupiers deemed this to be 'in the interest of public health'. In the French zone, although the denazification compromises produced similar results, they took a different form, as Anglo-American policies, acquired by default, were abandoned and replaced with French approaches. ${ }^{105}$ These new procedures similarly allowed for the retention of politically suspect technical specialists.

At first, the French authorities followed SHAEF instructions on the identification of former members of the NSDAP and their removal from positions of public responsibilities. Using questionnaires and blacklists compiled by the Americans, they attempted to categorize individuals into one of five categories of guilt. Through the application of SHAEF criteria, by May 1946 almost 11,000 individuals deemed to have been 'Nazi leaders' had been arrested and interned. 106

But from the start there was significant opposition to the questionnaires and the inflexible categories they generated. ${ }^{107}$ Less than six months into the occupation, Laffon and his staff rejected the denazification criteria used in the other zones and replaced them with a new concept of German 'self-purification' (auto-épuration). The new procedure involved individual assessment of Germans by Germans, using local testimony and evaluation. Where until then an individual's (non-)membership of the NSDAP (and dates of joining) was sufficient evidence, now local and provincial German denazification commissions were to consider a range of evidence available in each case, so as to determine the degree of complicity or guilt. The commissions would be constituted from members of the same profession as the accused, and representatives from political parties, trade unions, and former victims of the Nazi regime. They would have the power to impose sanctions, such as forced retirement, demotion, or dismissals without pension (but the French governors could veto their decisions or demand further investigations). $\frac{108}{}$

Soon, French denazification procedure differed from that in the other zones in three main points: first, it rejected party membership as a sufficient sign of guilt and, conversely, non-membership as a sign of innocence; second, it insisted on examining individual cases on their merits, instead of using predetermined categories; and third, it prescribed that the process had to be run by the Germans themselves, under French direction.

Laffon explained in a memorandum that he was particularly concerned about the likely effects of Anglo-American denazification procedures on 'anti-Nazi elements', who might, in their despair, refuse to cooperate with the French occupation authorities. ${ }^{109}$ By contrast, the new system would be 'both more thorough and more systematic'. A report from November 1945 explained that the Germans should take over denazification for both psychological and political reasons. They were motivated by 'a certain psychological interest that does not directly affect the French authorities in their operation of political justice'. The Germans had “ "lived" the Nazi regime', and were 'better able to assess the elements of the inquiry than the French officers, many of whom have experienced Germany only since the occupation', and were therefore 'ill-prepared to perform denazification'. There were also political calculations. AntiNazi Germans were 'not necessarily Francophiles', the report noted, and they might form 'a block against the occupiers if they had to testify before a French court'. Moreover, if the Germans took responsibilities for denazification 'in inevitable cases where injustices are committed, the French won't be blamed'. Nonetheless, the report went on, the French occupation authorities would still ultimately be in charge: they would select and approve the members of the German commissions, and would monitor (and if necessary, veto) proposed sanctions. ${ }^{110}$ 
That, at least, was the idea. In practice, the old SHAEF system and the new French procedure ran parallel for some time, creating confusion and inconsistencies. ${ }^{111}$ Another report from November 1945 noted that denazification was a complex problem, since it had to find a way to remove supporters of the Nazi regime from positions of influence, without abetting those 'solely driven by feelings of revenge'. There were still 'no appreciable results' to show from the new system, which had already been in operation for several months. ${ }^{112}$ A report from the following month observed that the denazification commissions could only deal with around 100 cases per day. New commissions were being created where possible, but they were limited — of course — by personnel shortages. And it was back-breaking work: 'all the French denazification staff had to work 9 to 12 hours a day'. Despite this, the report stated, there were already 'some successes', and the German members of the commissions took their work very seriously. Any differences of opinion could usually be resolved by the deputies of the German provincial administrations, who had specific responsibility for denazification matters. 113

Apart from an unrealistic time schedule, denazification in the French zone was also criticized for significant regional variation, as each decentralized Land authority developed its own procedures. All attempted to assess individual cases on their merits, as Laffon had specified, but some (such as in Württemberg) were admired for their fine-tuning and for being able to determine shades of individual guilt, while others struggled under the weight of cases. Even at the local level there was significant variation, and different commissions reacted differently to similar evidence. The Germans, one memorandum noted, often did not know what to do and needed further guidance, in particular where medical staff was concerned. The fact that some doctors were allowed to practise while others in a similar situation were suspended, was 'very disadvantageous'. ${ }^{114}$ Criticism from inside the zone, from other zones (particularly the American), and from France led military government staff to adapt or change procedures. ${ }^{115}$ But by spring 1947 , a report from April proudly noted, 476,000 cases had been examined from a population of just under 2 million, resulting in sanctions in 39.2 per cent of cases - which compared respectably to the British and American zones. ${ }^{116}$ This figure disguised great variation not just across the regions and provinces, but also in the different professions to be denazified. Denazification was strictest in the field of education, where fewer than 50 per cent of the old elementary and secondary school teachers were kept on, and the police, but far fewer proportions were punished among those who worked in industry, public works, science, and above all medicine. ${ }^{117}$

The procedure was different from the other zones, but the results - at least as far as they concerned the medical profession and health offices-were very similar. Just as in the other zones, politically suspect specialists deemed to be indispensable were widely tolerated and exempted from cleansing procedures. That was the case even though in the French zone, too, the staff of the medical faculties, health offices, and health professions contained high percentages of formerly active, loyal Nazis. A recent estimate suggests that 75 per cent of members of the medical faculty of the University of Freiburg had joined the NSDAP. ${ }^{118}$ Even if party membership alone was no longer a sufficient criterion of an individual's complicity, French officers were in no doubt about the extent of the problem, and they continued to use party membership as a signifier of 'particularly strong activity within the party'. ${ }^{119} \mathrm{~A}$ French proposal to the Allied Health Committee in Berlin admitted frankly that there could be no 'question of eliminating all doctors belonging to the Party as they form the majority, up to 96 per cent in certain districts'. ${ }^{120}$

Faced with warnings that medical care and training were threatened by strict denazification, French officials initially responded by attempting to find replacements. It should be possible to eliminate the most dangerous elements while still providing care to the civilian population, one note from September 1945 maintained. If the removal of doctors presented a threat to public health, because they were 'indispensable in a particular location', a politically acceptable replacement should be found. ${ }^{121}$ But French health officers also wavered about how to define Nazi complicity. To eliminate all Nazi party members would surely be to 'imitate Nazi methods', one memorandum argued; better to 'show humanity and eliminate only those active Nazis'. But who the 'active Nazis' were was hard to define, since Germans' own testimony always claimed they had not been actively involved. ${ }^{122}$

Next came the decision to make temporary allowances which broke the rules. In October 1945 Laffon reminded his staff that the cleansing of vital fields (such as industry, agriculture, finance, and commerce) had to be conducted in a way that did not destroy 'any possibility of an early resumption of economic life'. ${ }^{123}$ Although it was wrong to continue to employ health officers who had been revoked by the denazification commissions, one memo admitted, it was often impossible to find replacements for them; so they would, as a temporary measure, have to continue their work. ${ }^{124}$ As in the other zones, denazification was hampered because it applied above all to medical administration, for which volunteers were hardest to find. M. Curial from the Health Directorate noted how 'inconvenient' it was to have to find replacements for indispensable health officials removed from their jobs. ${ }^{125}$ By February 1946 Laffon 
directed that since there were more jobs than qualified people, some Nazis would have to be employed —on the proviso that they should not be used in public functions, or, if possible, remain in their old jobs, and the employment offices were to keep a record of these unpalatable appointments. 26

These compromises mirrored those that took place in the other three zones. If anything, the flexibility of the French zone's system made them happen earlier. Members of the medical profession, in particular, benefited from a system of hearings before German denazification commissions. Doctors and health officers were well-respected authority figures, and able to defend themselves in front of their neighbours and colleagues. And many managed to argue, consistently and convincingly, that doctors by their nature were above politics. They were treated more leniently by the commissions than other professions, and often cleared on the spot. ${ }^{127}$ Across the French zone, the proportion of cases examined and sanctions taken against was significantly lower in the health professions than in any other field. ${ }^{128}$

\section{Confrontations}

In 1949, an account of the work of the Health Directorate during the occupation observed that the public health picture had improved quickly after the initial months of chaos: by the summer of 1946, no epidemics were in evidence in French occupied territory, and the mortality rate was low and far exceeded by births. Diseases such as typhus, cholera, and dysentery, which continued to plague those parts of the country flooded with refugees, were in sharp decline. Diphtheria rates were declining as a result of the systematic vaccination programmes. The number of hospital beds appeared to be sufficient to cope with demands (even if the rate occupancy was very high), and continued to rise. Even the numbers of beds in tuberculosis sanatoria had increased, from only just over 2,000 in 1946 to over 6,000 in 1948 , once some of the requisitioned beds had been returned. ${ }^{129}$

But this benign official picture of public health progress obscures significant tensions. There were contradictions in all zones: between different sections of the occupation authorities, and between occupiers and the occupied population. A number of them centred around, and impacted upon, public health. In the French zone, some of these tensions became more acute and crippling than elsewhere because they were fuelled by the widespread unpopularity of the occupiers. They were disliked not just by the Germans. French occupation officers, both in the abstract and the concrete, were often scorned and parodied by the Americans, who portrayed them as 'officious', 'bureaucratic', conceited, pompous, or excessively nationalist. ${ }^{130}$ As one British soldier mocked, the American's 'dislike of the French was born in Normandy, and neither God nor Eisenhower can change it'. 131

But it was Germans' dissatisfaction with the French that dominated reports. In the contemporary press the French zone was described as 'the step-child among the four zones', run by a country 'which, itself, has come out of the war impoverished and diminished in importance'. ${ }^{132}$ Kurt Schumacher, leader of the Social Democratic Party in the British zone and later in the Federal Republic, described the French as the 'Russians of the West' (Westrussen) - as unwelcomed and loathed by the population of the zone as the Soviets were in theirs. ${ }^{133}$ But as Michael Balfour, a member of the British Element of the Control Commission (CCG(BE) ) in Berlin, qualified: the two were not hated in quite the same terms. German animosity towards the Soviets 'was fed by habitual Teuton scorn of Slavs', he thought 'nobody could deny that the French, for all their Negro troops and the stories of their degeneration, were a cultured race'. Nonetheless, he reported, the Germans' perception was that '[ $t$ ] he British like us but don't always notice that we are there, the Americans like us but treat us like badly behaved children, the French hate us on equal terms'. 134 Accounts of French revenge, pillage, and rape amplified such views. ${ }^{135}$ Above all the French were resented for being there at all.

Public health work was influenced by the tendency of the Germans to look beyond their zone, and to compare their lot with that of other parts of the country. ${ }^{136}$ The French zone, like the Soviet, never did very well in comparisons with the British and Americans, in particular falling short of the behaviour, influence, and material wealth of the United States. ${ }^{137}$ Fearing that France was in danger of 'losing the peace' 138 _ of being unable to implement its occupation agenda if the German population became ever more hostile — one response was to encourage fraternization between French occupation officers and the German population. The non-fraternization rule was one of the SHAEF directives the French authorities had inherited after joining the occupying powers. Paul Falkenburger, the young French public education officer, remembered that one of the few specific instructions before taking up his job in Freiburg, was not to fraternize with the occupied population. In practice, he found it easy to circumvent the rules. Like most of his colleagues he went to work in civilian clothes, and his superior — the military governor of Baden — was happy enough 
to relax the rules. ${ }^{139}$ In December 1945 General Koenig authorized French soldiers of all ranks to circulate among German civilians. Even private visits were acceptable, if they adhered to 'the correct attitude and rules'. Although French troops were in principle forbidden from lodging with German civilians, Koenig noted that this would be permitted where 'certain difficulties of billeting' arose. 140

Once the ban was lifted, Laffon and his staff actively encouraged contact. Fraternization at cultural, religious, and musical events was desirable in principle, Laffon declared, even if some French officers regrettably showed little discretion and had relations with former Nazis. ${ }^{141}$ The essential point was that good French behaviour and friendly associations with the Germans were essential components of the French mission in Germany. To the Germans, the French should be "not merely the functionaries who administer them with the funds of their military government, but men and women whom they meet in the streets, in the shops, the soldiers whom they see coming out of a dance on Sunday or children returning in the evening from a lycée or a school'. Laffon regretted that ' $[t]$ oo many cases' were reported to him which "show that too many French in the occupation give the appearance of a true spirit of "colonialist" or even "racist". For too many Frenchmen the Germans are slaves who do not have the right even to elementary politeness.' This would not do. By early 1947 contacts and relations had normalized and prospered, particularly once increasing numbers of French officers had brought their families to settle in the zone, Laffon was relieved to convey. ${ }^{142}$

Exchange trips, conferences, and other shared events were an immediately visible feature of this policy. Paul Falkenburger fondly remembered initiatives such as a meeting of French and German students in Titisee in the Black Forest, which resulted in a number of Franco-German marriages. ${ }^{143}$ German scientists, doctors, and health officers were among the first to take part in these new exchanges, which, they said, often simply continued older FrancoGerman scientific and medical collaborations. ${ }^{144}$ The new policy of scientific and cultural 'fraternization' was in evidence when the British psychiatrist E. B. Strauss toured the American and French occupation zones in spring 1946. While in the French zone he took part in an international conference of psychiatrists and neurologists at the University of Tübingen's nerve clinic. He was particularly impressed, he wrote in his report for the Medical Research Council, by the visionary French administrator of the university, who told him: 'we French cannot impress the Germans with our material power and resources, which are non-existent; so we concentrate on supporting and reinforcing the cultural life of the country. It is important that the Germans should realise that the French care for the arts and sciences as much as themselves. ${ }^{145}$ One example was the medical officer for the Berlin district Reinickendorf (in the French sector), a Dr Bloss, whom the French military government invited to the Hôpital Saint-Louis in Paris to learn about a new method of healing serious wounds. Upon his return, Dr Bloss gave lectures and talks to his colleagues about what he had learned, and repeatedly emphasized the friendly, cooperative, and accommodating treatment he had received in Paris. 146

Apart from this focus on Franco-German relations, a second strategy to overcome the unpopularity of the French occupation was the military government's decision to fight bad press - in France and abroad — with detailed accounts of the accomplishments of its different departments. In early 1948, General Koenig instructed the heads of the six directorates to 'popularize' their activities and achievements for public consumption, and particularly for French journalists, who until then had mainly received information from the Germans themselves. ${ }^{147}$ Médecin-Général F. Desplats's narrative of the Health Directorate's work, covering the period from the beginning of its existence in July 1945 to spring 1949, was one product of this popularization drive. ${ }^{148}$ A largely descriptive account of how the Health Directorate successfully tackled a series of public health problems, it resembled, in both approach and substance, health officers' histories of those of the other military governments. 149

Despite cultural propaganda and promotional histories, however, public health work in the French zone, according to German health officers, continued to be cast in an unfavourable light by a combination of French policies and discouraging comparisons to other parts of the country. Health officers' work was caught between the priorities of French reconstruction and German recovery. Nowhere were these conflicts more visible, and vocal, than in arguments about food and food shortages, which quickly spilled over into debates about public health.

From the moment they set foot on German soil, the needs of the French occupation troops appeared to come into conflict with those of the occupied population. In contrast to the British and American zones, but like the Soviet zone, the territory occupied by France had to provide much of the occupation troops' upkeep. The burden on each inhabitant, F. Roy Willis has calculated, was proportionately heavier in the French zone than in the British or American. ${ }^{150}$ The high density of military government officers and the fact that families of occupation staff were 
encouraged to settle in the zone, added bodies to be housed and mouths to be fed. One report from 1946 estimated that around 17,000 French people lived in the town of Baden-Baden alone. It thought that the 'amounts of foodstuffs used by the occupying forces throughout the zone must be considerable, especially if it is remembered that the rations accorded them are far superior to those given out to the average person. To the number of administrators accompanied by their families must be added numerous mobilized troop contingents, which are rationed in Germany. 151

Some French reports observed that German rations during the first occupation year were in the region of 1,000 to 1,300 calories per person per day, and rose to at least 1,400 calories in 1947 and 1,869 in $1948 .{ }^{152}$ But others reported extended drops to significantly below the 1,000 calory-mark for the normal consumer. ${ }^{153}$ In March 1946 the Health Directorate initiated a series of nutrition surveys, which confirmed the insufficiency of food rations. ${ }^{154}$ But, unlike in the British zone, it was not the data itself that was a source of conflict, rather the policies that produced them. German sources directly blamed the occupation army's excesses for the lack of food. Karl Brandt, a German agricultural economist who had fled to the United States in 1933, criticized the fact that the food shortages, felt throughout Germany in 1947, were at their worst in the French zone, where the occupation army lived off the land. Brandt's argument was also a political one: European security and unity demanded the reconstruction of Germany as an equal partner, he maintained, but this project was undermined by French economic policy in the French zone. ${ }^{155}$

German doctors assumed the roles of spokesmen for the German population at large. Food shortages had a direct impact on German public health, they argued. Members of the University of Tübingen's medical faculty produced a series of four memoranda on the food situation from August 1945 until summer 1946, which contained reports from various medical specialists about the physical effects of the food shortage. They painted a picture of a town on the verge of a hunger catastrophe. For the Germans real hunger had come with the occupation army; the physical destruction, lack of transport, and disruption of trade with the lost eastern territories were all exacerbated by the French living off the fat of the zone. One of their recommendations was the reduction of the population's working day to between four and six hours, 'to save calories'. ${ }^{156}$ Throughout the first years of the occupation, German health officers insisted that lack of food was directly linked to rising rates of tuberculosis, the diminution of the population's physical and mental capacities, and the declining health of children. ${ }^{157}$

Political rather than medical concerns appeared to dictate the French allocation of food. They discussed food as part of the ever-present question of 'deserving': after all, as the French representative at the Nuremberg trials testified, at least 150,000 French people had died as a direct result of undernourishment caused by German occupation, and thousands more as an indirect result of it. ${ }^{158}$ Food rations available to Germans were also frequently compared to official rations in France. ${ }^{159}$ Additional food rations were given to German members of the Resistance and German political refugees in the Saarland who had fought for the FFI. ${ }^{160}$ French nutrition policy was also used to bolster reeducation programmes through giving ration supplements to participants at international youth camps and to pupils and schoolteachers living away from their families. ${ }^{161}$ Desplats wrote laconically that food questions had 'rapidly turned into top priorities because of the repercussions on the general political situation'. ${ }^{162}$

Similar, if less emotional, confrontations between German health officers and the French authorities took place over the requisitioning of German hospitals, and shortages of drugs and other medical supplies. Like the food shortages, both issues were part of the bigger debate about economic policy in the zone and the relationship of France's reconstruction to Germany's recovery. But while in the food controversy the French Health Directorate often sided with the Germans, here it was even more directly exposed to the contradictory nature of its assignment: like its counterpart in the Soviet zone, it was charged with the dual tasks of having to protect German public health, while at the same time prioritizing the health of French citizens and assisting French reparations and dismantling units. When in July 1945 French health officers toured and studied the German pharmaceutical factories and laboratories in the zone, they did so not just 'to protect them against looting', but primarily 'to put them back into action to produce the most indispensable products' for export to France. By October 1945, pharmaceutical production in the zone 'permitted ... the supply of France with products of prime necessity which were totally lacking'. ${ }^{163}$

France's experience as an occupier was from the beginning shaped by the history of Franco-German relations. One of the lasting effects of this historical baggage, though elusive, was that it stimulated Frenchmen's search for France's 'lost greatness'. ${ }^{164}$ French politicians' and diplomats' ambition for France to be once again recognized as a Great Power, as Stanley Hoffmann has argued, 'inspired the entire new politico-administrative class coming out of the war and the Resistance ... Since humiliation had to be erased, since its most painful sign was the loss of precious rank, the high level before the fall had to be reconquered.' 165 As they marched into Germany, and indeed throughout the post- 
war decades, the French authorities tried to overcome the stigma of defeat and loss of power. The fact that France's place among the occupiers was in reality far more a product of the decisions and actions of the other Allies than of French efforts simply added to the urgency of that desire. By August 1944, French politicians insisted that the embarrassments of 1940 were now light years away, but in reality the scars of defeat and German rule ran deep. Signs could be detected not just in the nature of French soldiers' conduct and their daily interactions with the German population, but much earlier, even before French troops set foot on German soil. Conceptually, the goals and priorities of the occupation, and the political solutions available to French leaders to achieve them, were a direct product of this history.

And yet, by 1949, the initial goals and priorities of the French project had been largely overturned by the French zone's growing proximity to the American and British zones, and its integration into 'Trizonia', the future Federal Republic of Germany. It was only through political and material support that the persistent conflicts and confrontations in the French zone could be resolved. By then, France itself had already been a beneficiary of substantial amounts of Marshall aid. ${ }^{166}$ The new alignments had immediate and visible effects in the zone. In the French sector of Berlin food rations increased markedly during the Soviet blockade. ${ }^{167}$ Or, according to Desplats's history, the twelve months from June 1948 to June 1949 saw a complete transformation of the German economy, a currency reform, and the arrival of Marshall aid for imports of both food and medical supplies. Thereafter, drugs such as penicillin, streptomycin, and insulin could be imported, and pharmaceutical supplies in the zone soon reached or even exceeded pre-war levels. By the time the nutrition surveys were terminated in December 1948, health officers reported 'very noticeable improvements in the nutritional state of population' in the wake of the currency reform. By then, too, the sanatoria in the Black Forest, which the French military government had acquired for use by French children, prisoners of war, and concentration camp survivors, were returned to the German authorities, because of, as Desplats put it, 'a change in orientation' by the military government. ${ }^{168}$

\section{Footnotes}

1 'The Germans will pay'. In 1919 the slogan had been 'Le boche payera tout' ('the Germans will pay all'). See Gerd Krumeich, 'Vergleichende Aspekte der Kriegsschulddebatte nach dem ersten Weltkrieg', in Wolfgang Michalka (ed.), Der Erste Weltkrieg: Wirkung, Wahrnehmung, Analyse (Weyarn, 1997), 919. The slogan's English counterpart, 'We will squeeze the orange until the pips squeak' (often attributed to Lloyd George) was coined by Eric Geddes, a British Conservative politician, see Alfred F. Havighurst, Britain in Transition: The Twentieth Century (1962; Chicago, 4th edn. 1985), 148. Harold Nicolson, Peacemaking, 1919 (1933; London, new edn. 1945), 14. Charles Callan Tansill, 'The United States and the Road to War in Europe', in Harry Elmer Barnes (ed.), Perpetual War for Perpetual Peace: A Critical Examination of the Foreign Policy of Franklin Delano Roosevelt and Its Aftermath (Caldwell, Ida., 1953).

2 Edmond Vermeil, Germany's Three Reichs: Their History and Culture, trans. E. W. Dickes (London, 1944), 409. This is a reissued and translated version of Vermeil's L'Allemagne: Essai d'explication (Paris, 1940) which was first published just months before France's defeat and then seized and banned by the German occupation authorities.

3 Vermeil, Germany's Three Reichs, 407.

4 A. L. Rowse, 'What Is Wrong with the Germans?' (1937); repr. in Rowse, The End of an Epoch (London, 1947), 181-92.

5 Vermeil, Germany's Three Reichs, 408-9.

6 Charles de Gaulle, The Complete War Memoirs of Charles de Gaulle (1954-9; London, 1998), 720-1.

7 Jürgen Klöckler, Abendland -Alpenland-Alemannien: Frankreich und die Neugliederungsdiskussion in Südwestdeutschland 19451947 (Oldenbourg, 1998), 52 ff.

8 Vermeil, Germany's Three Reichs, 409. Robert Verdier and Pierre Guidoni (eds.), Les Socialistes en Résistance, 1940-1944: Combats et débats (Paris, 1999).

9 Johannes Glasneck, Léon Blum: Republikaner und Sozialist (Frankfurt, 2003). Louise Elliott Dalby, Léon Blum: Evolution of a Socialist (New York, 1963).

10 Léon Blum, 'Aprés un bombardement du camp, Juin 1944', in 'Notes d'Allemagne', repr. in L'Euvre de Léon Blum: Mémoires; La Prison et le procès; A l'échelle humaine; 1940-1945 (Paris, 1955), 513.

11 Blum was one of the 'Vichy 80', a group of French parliamentarians who on 10 July 1940 voted against the constitutional amendment 
that dissolved the Third Republic and established the Vichy administration under Marshall Philippe Pétain. He was arrested and charged with treason at the Riom Trial.

12 Le Populaire, 16 Aug. 1945, quoted in Dalby, Léon Blum, 374.

13 Le Populaire, 21-2 and 28 June 1946, both quoted in Dalby, Léon Blum , 374-5.

14 Le Populaire, 25 Mar. 1946, in Dalby, Léon Blum, 377.

15 In 1951-2 he served as deputy prime minister of France, and in 1953 briefly as prime minister. Between 1955 and 1958 Mayer was president of the High Authority of the European Coal and Steel Community. Contrast with Carlo Schmid's vision of Europe: Petra Weber, 'Guter Patriot und guter Europäer — das Europa Carlo Schmids', in Volker Depkat and Piero Graglia (eds.), Entscheidung für Europa-Decidere l'Europa: Erfahrung, Zeitgeist und politische Herausforderungen am Beginn der europäischen Integration (Berlin, 2010), 243-62.

16 Wolfram Kaiser, Christian Democracy and the Origins of the European Union (Cambridge, 2007).

17 Alan Milward, The European Rescue of the Nation-State (2nd edn. London, 2000), 335.

18 Milward, European Rescue, 325 ff. Kaiser, Christian Democracy, 3.

19 The CFLN was formed on 3 June 1943 under the leadership of Charles de Gaulle and Henri Giraud to coordinate the campaign to liberate France; from Nov. onwards it was run by de Gaulle alone. It provided the seeds of the later Provisional Government of the French Republic, under de Gaulle's premiership.

20 Alain Lattard, 'Zielkonflikte französischer Besatzungspolitik in Deutschland: Der Streit Laffon-Koenig, 1945-1947', Vierteljahreshefte für Zeitgeschichte, 39/1 (Jan. 1991), 1-35, at 7.

21 Lattard, 'Zielkonflikte', 7. Robert Aron, Histoire de la Libération de la France (Paris, 1959). Charles-Louis Foulon, Le Pouvoir en province à la Libération (Paris, 1975).

22 On Laffon, see 'Zaunkönig in der Ente: Schlußstrich under die Erbfeindschaft', Der Spiegel, 32/1949, 4 Aug. 1949, 5. Lattard, 'Zielkonflikte'. Klöckler, Abendland.

23 Robert Gildea, France Since 1945 (Oxford, 2002), 41.

24 F. Roy Willis, The French in Germany, 1945-1949 (Stanford, Calif., 1962), 45-6. Also see Willis, France, Germany and the New Europe, $15 \mathrm{f}$.

25 Willis, France, Germany and the New Europe, 35.

26 Klöckler, Abendland, 50 ff. On Mayer's work, Raymond Poidevin, 'René Mayer et la politique extérieure de la France', Revue d'histoire de la deuxième guerre mondiale et des conflits contemporains, 134 (1984), 73-97.

27 Foundation for Foreign Affairs, Field Report on the French Zone in Germany (Washington DC, 1946), 5. On the EAC's decision to divide Baden and Württemberg along the Karlsruhe-Munich autobahn, Philip Mosely, 'The Occupation of Germany', Foreign Affairs (July 1950).

28 A French translation was completed by Dec. 1944, published in Mar. 1945 as A.M.F.A. Mémento pour les officiers de détachements de gouverment militaire. Jérôme Vaillant, 'Bedeutung und Ausmaß des französischen Einflusses auf die kulturelle Entwicklung im Nachkriegsdeutschland', in Vaillant (ed.), Französische Kulturpolitik in Deutschland, 1945-1949: Berichte und Dokumente (Konstanz, 1984), 11; 1st pub. as Vaillant (ed.), La Dénazification par les vainqueurs: La Politique culturelle des occupants en Allemagne 19451949 (Lille, 1981). Reinhard Grohnert, Die Entnazifizierung in Baden 1945-1949: Konzeptionen und Praxis der 'Epuration'am Beispiel eines Landes der französischen Besatzungszone (Stuttgart, 1991), 13. COL AC 836, Enemy Branch, Foreign Office and Ministry of Warfare, London, ‘Germany Basic Handbook’, Aug. 1944.

29 'Note sur le problème allemand' (19 July 1945), 'Directives pour notre action en Allemagne' (19 July 1945) and 'Compte-rendu de la séance du comité interministériel' (20 July 1947), all in Alain Lattard, Gewerkschaften und Arbeitgeber in Rheinland-Pfalz unter französischer Besatzung, 1945-1949 (Mainz, 1988).

30 Lattard, 'Zielkonflikte'.

31 Henri Humblot, 'Kontrolle und Anregung der Jugendbewegungen in Süd-Würtemberg: Ein Erlebnisbericht aus den Jahren 1945 bis 1949’, in Vaillant (ed.), Französische Kulturpolitik in Deutschland, 1945-1949. Humblot helped to establish the Internationale Bund 
für Sozialarbeit in 1949 in Tübingen (since 1995 known as the Internationale Bund, IB), see Philipp Mausshardt, 'Wer war Henri? Ehemalige Hitlerjungen und der Internationale Bund', Die Zeit, 29 Nov. 1996.

32 Grohnert, Die Entnazifizierung in Baden, 13-14.

33 Willis, France, Germany and the New Europe, 42.

34 COL AB 35/1, 'Chapitre VI: Santé Publique' [undated]. Compare with 'Chapter VI: Public Health', in SHAEF, Handbook for Military Government in Germany prior to Defeat or Surrender (incorporating revision 1-20 December 1944) (Washington, 1944). Also see TNA, WO 219/3882, SHAEF, Technical Manual for Public Health Officers (prepared 22 Nov. 1944, rev. 2 Feb. 1945).

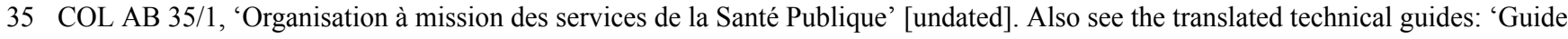
technique No. 1 sur la Santé Publique en Allemagne', 'Guide technique No. 2 de la Santé Publique en Allemagne: Bibliographie politique, administrative et professionnelle', 'Guide technique No. 3 de la Santé Publique en Allemagne: Projets d'instructions a remettre aux Amtsärzte', 'Extraits du Guide d'administration des centres de rassemblement: Personnes deplacées, réfugiés et service social', 'Directives pour la Santé Publique du Gouvernment Militaire: Extraits du "Technical Manual for Public Health Officers" , 'Organisation du 5ème Bureau de SHAEF', 'Collection des lois de la Santé Publique d'après le volume "Sammlung Deutscher Gesundheitsgesetze de Ritter-Möllens-Hallbauer”- tome II administration de la santé (Gesundheitsverwaltung)', and other guides in this file.

COL AB 35/1, 'Chapitre VI: Santé Publique' [undated]. Compare with 'Chapter VI: Public Health', in SHAEF, Handbook for Military Government. TNA, WO 219/3882, SHAEF, Technical Manual for Public Health Officers (prepared on 22 Nov. 1944, rev. 2 Feb. 1945).

37 COL AB 35/1, 'Chapitre VI: Santé Publique' [undated].

38 The Civil Affairs Handbook is listed in the catalogue of the library of the GMZFO's Direction Générale des Affaires Adminstratives (DGAA), see COL AC 707/1, 'Catalogue de la bibliothèque de la Direction Générale des Affaires administratives' [undated].

COL AB 34/4, Forces Expéditionnaires Alliées, Division G5, A. E. Grasett (Lieutenant General, Assistant Chief of Staff of G5, SHAEF), 'Manuel technique à l'usage des officiers de la Santé Publique du Gouvernment Militiare' [undated].

40 e.g. COL AB 35/1, 'List of health departments in South Germany as of 1 October 1938' [in English, undated], 'Health personnel in south Germany as of 1 January 1939' [in English, undated], and various handwritten notes in this file.

41 COL AB 35/1, 'Chapitre VI: Santé Publique' [undated], para. 634.

42 e.g. Karl Epping, État et Santé (Paris, 1942) contained chapters by Conti, Hans Reiter, Otmar von Verschuer, Eugen Fischer, and Arthur Scheunert. Otmar von Verschuer, Manuel d'eugénique et hérédité humaine (trans. from the German by George Montandon, Paris, 1943). On Verschuer, see Robert Proctor, Racial Hygiene: Medicine under the Nazis (Cambridge, Mass., 1988); Paul Weindling, ، “Tales from Nuremberg”: The Kaiser Wilhelm Institute for Anthropology and Allied Medical War Crimes Policy', in Doris Kaufmann (ed.), Geschichte der Kaiser-Wilhelm-Gesellschaft im Nationalsozialismus: Bestandsaufnahme und Perspektiven der Forschung, ii (Goettingen, 2000), 635-52; Paul Weindling, 'Weimar Eugenics: The Kaiser-Wilhelm Institute for Anthropology, Human Heredity and Eugenics in Social Context', Annals of Science, 42 (1985), 303-1810.1080/00033798500200221 [PubMed: 11620696] [CrossRef].

43 COL AC 707/1, 'Catalogue de la bibliothèque de la Direction Générale des Affaires administratives’ [undated].

44 COL AB 35/1, 'Le Médecin allemand' (Paris, 11 Feb. [1945]).

45 COL AB 35/1, 'Le Médecin allemand'.

46 COL AB 35/1, 'Le Médecin allemand'.

47 Willis, France, Germany and the New Europe, 33.

48 Robert Aron in collaboration with Georgette Elgey, The Vichy Regime, 1940-1944 (London, 1958) (1st French edn. 1955).

49 Mission Militaire pour les Affaires Allemandes, AMFA, Bulletin d'information, No. 1, Mar. 1945, 3. Also quoted in Willis, The French in Germany, 148, 93.

50 Willis, France, Germany and the New Europe, 34. On the holiday camps, see 'In the French Zone-System secluded from the rest of Germany-a rigid economic policy', The Times, 20 Dec. 1946. On the sanatoria in the Black Forest, see COL AB 35/2, Docteur F. 
Desplats, 'Commandement en chef français en Allemage, Gouvernement Militaire de la Zone Française d'Occupation, la Direction de la Santé Publique \& Aide Sociale de juillet 1945 au 30 mai 1949’ [30 May 1949].

51 Willis, France, Germany and the New Europe, 33. General du Souzy, 'Jean de Lattre: "Grand de France", in Commandant Storelli et al. (eds.), Jean de Lattre, maréchal de France: Le Soldat, l’homme, le politique (Paris1953), 81.

52 Jean Planchais, 'Le Malaise de l'armée', Tribune libre, 16 (1958), 24, in Willis, France, Germany and the New Europe, 34.

53 LAB C Rep. 101/1928, 'Verordung', 12 Aug. 1945.

54 'Le Voyage du Général de Gaulle en Allemagne occupée', La Revue de la Zone Française (GMZFO, Direction de l’Information), 1 (15 Nov. 1945), 1-11.

55 Charles de Gaulle quoted in 'Le Voyage du Général de Gaulle en Allemagne occupée'.

56 Rovan quoted in Matthieu Osmont, 'René Cheval (1918-1986), itinéraire d'un médiateur franco-allemand', Relations internationales, 2/126 (2006), 31-49, at 34. See Rovan's obituary in the Telegraph, 10 Aug. 2004.

57 Joseph Rovan, Erinnerungen eines Franzosen, der einmal Deutscher war (Munich, 2003); 1st pub. as Mémoires d'un Français qui se souvient d'avoir été Allemand (Paris, 1999).

58 Joseph Rovan, 'L'Allemagne de nos mérites', Esprit, 13/115 (1 Oct. 1945).

59 Foundation for Foreign Affairs, Field Report, 17.

60 COL AOR 1/1a, 'Roger Humbert, Politique allemande de la France', tape of interview.

61 Jérôme Vaillant, 'Bedeutung und Ausmaß', 11.

62 Rovan quoted in Lattard, 'Zielkonflikte'.

63 Rainer Hudemann, 'Zentralismus und Dezentralisierung in der französischen Deutschland- und Besatzungspolitik 1945-1947', in Winfried Becker (ed.), Die Kapitulierung von 1945 und der Neubeginn in Deutschland (Cologne, 1987), 181-209. Clay observed that although France supported German dismemberment, it practised administrative centralization in its own zone, see Lattard, 'Zielkonflikte', 21. Also see the newspaper clipping and minutes in TNA, FO 371/46992, 'French Policy in Germany: Powers of Central Administration - from our own correspondent, Paris, 2 December 1945', The Times, 3 Dec. 1945.

64 Henri Humblot, 'Kontrolle und Anregung der Jugendbewegungen in Süd-Würtemberg: Ein Erlebnisbericht aus den Jahren 1945 bis 1949’, in Vaillant (ed.), Französische Kulturpolitik in Deutschland, 1945-1949.

65 e.g. COL AB 35/3, L’Inspecteur Général Coulon (Directeur de la Santé Publique) to Monsieur le Directeur du Personnel et du Matériel et du Budget, [23 Jan. 1946].

66 COL AB 35/2, Desplats, 'La Direction de la Santé Publique'.

67 COL AB 35/3, L'Inspecteur Général Coulon, feuille de renseignements—formation: Direction de la Santé Publique, 11 Sept. 1945.

68 On Rivet, see Christine Laurière, Paul Rivet: Le Savant et le politique (Paris, 2008). On Soustelle, see Denis Rolland, 'Jacques Soustelle, de l'ethnologie à la politique, 1939-1943', Revue d'histoire moderne et contemporaine, 1 (1996), 137-50.

69 He died in Mainz in 1965. See Joseph Walk, Kurzbiographien zur Geschichte der Juden, 1918-1945 (Munich 1988), and Werner Röder and Herbert A. Strauss (eds.), Biographisches Handbuch der deutschsprachigen Emigration nach 1933/International Biographical Dictionary of Central European Emigres 1933-1945, 3 vols. (Munich and New York, 1980-3). Paul Falkenburger (with Corine Defrance), 'Ich bin ein Berliner': Berlin, Paris, Bonn-la voie d'un interprète (Paris, 2006).

70 Falkenburger, 'Ich bin ein Berliner'.

71 Falkenburger, 'Ich bin ein Berliner'.

72 'In the French Zone', The Times, 20 Dec. 1946.

73 Berlin: 30\% total destruction, 45\% partial destruction, and 25\% intact. British zone: $33 \%$ total destruction, $46 \%$ partial destruction, 21\%per cent intact. American zone: $33 \%$ total destruction, $48 \%$ partial destruction, $19 \%$ intact. Soviet zone: $23 \%$ total destruction, 38\% partial destruction, 39\% intact. French zone: 44\% total destruction, 45\% partial destruction, 11\% intact. André Piettre, L'Économie allemande contemporaine (Allemagne occidentale) 1945-1952 (Paris, 1952), 67, quoting data from Deutschland- 
Jahrbuch (1949), 291. Also see Michael Balfour 'Four Power Control in Germany', in Balfour and John Mair, Four Power Control in Germany and Austria, 1945-1946 (Oxford, 1956), 8.

74 Foundation for Foreign Affairs, Field Report.

75 First French Army, Monthly Historical Report (Apr. 1945), 2 and Monthly Historical Report (May 1945), both quoted in Joseph R. Starr, Denazification, Occupation and Control of Germany, March-July 1945 (1950, Salisbury, 1977), 16.

76 Starr, Denazification.

77 Joel Carl Welty, The Hunger Year: In the French Zone of Germany (Beloit, Wis., 1983), 11, 17-18.

78 'Le Voyage du Général de Gaulle en Allemagne occupée'.

79 Starr, Denazification, 16-17.

80 Renée Bédarida, letter, 15 Oct. 1945, repr. in Renée Bédarida, 'Une française à Berlin en 1945', in Klaus Manfrass and Jean-Pierre Rioux (eds.), France-Allemagne 1944-1947: Akten des deutsch-französischen Historikerkolloquiums, Baden-Baden, 2.-5. Dezember 1986 (Paris, 1990), 149.

81 COL AOR 1/1a, 'Roger Humbert, Politique allemande de la France', recorded interview.

82 Earl F. Ziemke, The U.S. Army in the Occupation of Germany, 1944-1946 (Washington, 1990), 196.

83 COL AB 48/3, L'Inspecteur Général Coulon (Directeur de la Santé Publique, GMZFA) to Monsieur Sabatier (Directeur Général des Affaires Administratives), [summer 1945] and following draft letter to General Koenig. The price of typhus vaccine was apparently 114 francs per person, see COL AB 35/3, 'Note explicative concernant l'effectif budgetaire du Service Medical du GM' [undated].

84 COL AB 35/2, Desplats, 'La Direction de la Santé Publique'.

85 COL AB 47/4, Le Médecin Général Melnotte to Monsieur le Général Coulon, 6 Aug. 1945.

86 e.g. COL AB 47/4, memorandum on 'Vénéréologie', [1946], which lists VD measures, and 'Fiche de déclaration de maladie vénérienne'. COL AB 47/4, L’Inspecteur Général Coulon, 'Note concernant la lutte contre les maladies vénériennes', 17 Aug. 1945.

87 COL AB 47/4, L’Administrateur Général Laffon to Messieurs les Délégués Supérieurs pour le Gouvernement Militaire, 'Lutte contre les maladies vénériennes', 30 Aug. 1945.

88 LAB B Rep. 012/902-27, 21 June 1945, report by H. Lehmann (Gesundheitsamt Bezirk Wedding) to Magistrat der Stadt Berlin.

89 Eduard Seidler, Die Medizinische Fakultät der Albert-Ludwigs-Universität Freiburg im Breisgau (1993), 397.

90 Hans-Georg Hofer, 'Zwischen Reinigung und Reintegration: Die Freiburger Universitätsmedizin nach 1945', in Sigrid Oehler-Klein und Volker Roelcke (eds.), Vergangenheitspolitik in der universitären Medizin nach 1945 (Stuttgart, 2007), 250.

91 Hofer, 'Zwischen Reinigung und Reintegration'. Seidler, Die Medizinische Fakultät.

92 MG-CA Weekly Field Report, 28 Apr. 1945, No. 46, 9, quoted in Starr, Denazification, 9.

93 First French Army, 'Monthly Historical Report' (Apr. 1945), 11, quoted in Starr, Denazification, 67.

94 F. Desplats suggested this was because the French population contained a higher number of old people. COL AB 35/2, Desplats, 'La Direction de la Santé Publique'.

95 GMZFO, Zone Française d'Occupation en Allemagne, Résultats de six mois d'activité (May 1946), 49.

96 LAB C Rep. 118-59, 'Denkschrift zur Frage des Umsiedlerproblems in der Stadt Berlin', Magistrat der Stadt Berlin, Hauptamt für Sozialwesen, 16 Nov. 1945. Also see LAB B Rep. 012/166, Weekly reports on expellees and returning soldiers, 5 Nov. 1945.

97 e.g. LAB B Rep. 203/5114, Bezirksamt Wedding von Gross-Berlin to Gouvernement Militaire Francais du Grand-Berlin, 3 June and 3 July 1947.

98 'In the French Zone', The Times, 20 Dec. 1946. On competing estimates for the numbers of military government personnel in the other zones, see Balfour, 'Four Power Control in Germany', 102-6.

99 Willis, France, Germany and the New Europe, 34. Estimates in Klöckler, Abendland, 29. For an example of rumours about cuts to the French occupation apparatus, see TNA FO 371/64348, British Consulate General, Baden-Baden, to Ernest Bevin, Foreign Office, 21 Jan. 1947. 
100 COL AB 35/3, 'Note explicative concernant l'effectif budgetaire du Service Médical du GM' [undated].

101 A cut in the health budget in late 1946 meant that the pharmaceutical office of the French zone's health directorate was reduced to just a chief, a deputy, and 2 typists. COL AB 35/2, Desplats, 'La Direction de la Santé Publique'.

102 COL AB 35/1, 'Le Médecin allemand' (Paris, 11 Feb. [1945]).

103 LAB B Rep. 012/5, 'Bericht über die Dienstbesprechung am Donnerstag, dem 4.Oktober 1945’, 4 Oct. 1945.

104 LAB B Rep. 012/277, 'Vermerk über die Amtsarztsitzung am 14. November 1946 im großen Saal des Landesgesundheitsamtes’, 15 Nov. 1946.

105 The French had a separate term for this process: épuration, a purification or purge.

106 La Zone Française d'Occupation en Allemagne, Résultats de six mois d'activité (May 1946), 52.

107 COL AB 43/3, Emile Laffon to Messieurs les Administrateurs de Province, Baden-Baden, 22 Aug. 1945.

108 COL AB 43/3, Laffon to the Health Directorate, 19 Sept. 1945.

109 COL AB 43/3, Laffon to the Health Directorate, 19 Sept. 1945.

110 COL AB 43/4, 'Rapport General sur la dénazification en zone française d'occupation pour le mois de Novembre 1945'.

111 This has been highlighted by the older historiography of the French zone, see e.g. Klaus-Dietmar Henke, Politische Säuberung unter französischer Besatzung: Die Entnazifizierung in Württemberg-Hohenzollern (Stuttgart, 1981). Klaus-Dietmar Henke, 'Politik der Widersprüche: Zur Charakteristik der französischen Militärregierung in Deutschland nach dem Zweiten Weltkrieg', in Claus Scharf and Hans-Jürgen Schröder (eds.), Die Deutschlandpolitik Frankreichs und die französische Zone 1945-1949 (Wiesbaden, 1983), 49 90. Klaus-Dietmar Henke, 'Die Grenzen der politischen Säuberung in Deutschland nach 1945', in Ludolf Herbst (ed.), Westdeutschland 1945-1955: Unterwerfung, Kontrolle, Integration (Munich, 1986), 127-33.

112 COL AB 43/4, 'Rapport General sur la denazification en zone française d'occupation pour le mois de Novembre 1945'.

113 COL AB 43/3, 'Épuration de personnel allemand, rapport général au 31 Décembre 1945, Statistiques provisiores de l'épuration systematique' [31 Dec. 1945].

114 COL AB 43/3, note from F, 2 Mar. 1946. For similar complaints, also see COL AB 43/3, Dénazification du corps médical [1945].

115 On internal criticisms, see e.g. COL AB 43/3, GMZFO Cabinet Civil, Laffon to DGs, 'Objét: Dénazification', 2 Apr. 1947. On the criticisms voiced in the American and French press, see Grohnert, Die Entnazifizierung in Baden. On effects of the French system on American denazification policy, see R. Grohnert, 'Die "auto-épuration”: Der französische Sonderweg in der Entnazifizierung', in Edgar Wolfrum, Peter Fäßler, and Reinhard Grohnert (eds.), Krisenjahre und Aufbruchszeit: Alltag und Politik im französisch besetzten Baden 1945-1949 (Munich, 1996), 165-85.

116 COL AB 43/3, 'Rapport général sur l'épuration dans la Zone française d'Occupation en Allemagne à fin Avril 1947’.

117 Willis, France, Germany and the New Europe, 43. On the denazification of forestry workers and lawyers, see Grohnert, Die Entnazifizierung in Baden, 95-102. Evidence of the temporary and limited nature of denazification in the French zone is the existence of an influential lobby group of academics who had not yet been reinstated, the Verband der nicht-amtierenden (amtsverdrängten) Hochschullehrer, founded in Tübingen in 1950, Karsten Jedlitschka, Wissenschaft und Politik: Der Fall des Münchner Historikers Ulrich Crämer (1907-1992) (Berlin, 2006).

118 Silke Seemann, Die politische Säuberungen des Lehrkörpers der Freiburger Universität nach dem Ende des Zweiten Weltkriegs, 1945-1947 (Freiburg,2002); Silke Seemann, 'Entnazifizierung und Vergangenheitsbewältigung in der Medizinischen Fakultät nach 1945', in Bernd Grün, Hans-Georg Hofer, and Karl-Heinz Leven (eds.), Medizin und Nationalsozialismus: die Freiburger Medizinische Fakultät und das Klinikum in der Weimarer Republik und im 'Dritten Reich' (Frankfurt am Main, 2002), 471-95.

119 COL AB 43/4, Laffon to DGs, Épuration du corps médical [n.d.].

120 TNA, FO 1050/737, 'Measures proposed for the denazification of the German Medical Corps', paper submitted by French member for consideration at the 4th AHC meeting, 22 Sept. 1945. COL AB 43/4, 'Projet', transmitted to Berlin via telephone, 26 Sept. 1945. The Health Directive supplied the material for this proposal presented in Berlin, see COL AB 43/3, Health Directorate, 'Note pour la Commission de Berlin. Objet: Épuration des médecins’, 15 Sept. 1945.

121 COL AB 43/3, Health Directorate, 'Note pour la Commission de Berlin. Objet: Épuration des médecins', 15 Sept. 1945. 
122 COL AB 43/4, Memorandum on 'Dénazification du corps médical' [undated, late 1945].

123 COL AB 43/4, Laffon to DGs, 31 Oct. 1945.

124 COL AB 43/3, Laffon memo, 22 Dec. 1945. Desplats's history of the Direction de la Santé Publique \& Aide Sociale also states that the 'period of chaos gradually ceased as we put into place new medical personnel first with provisional, then with definitive licences'. COL AB 35/2, Desplats, 'La Direction de la Santé Publique'.

125 COL AB 43/3, Générale des Affaires Administratives, memorandum on a meeting with M. Curial, 22 Dec. 1945.

126 COL AB 43/3, Laffon to DGs, 8 Feb. 1946.

127 COL AB 43/3, Laffon memo, 22 Dec. 1945.

128 See e.g. Zone Française d'Occupation en Allemagne, 'Résultats de six mois d'activité', May 1946, 52—also reproduced in table 28.

129 COL AB 35/2, Desplats, 'La Direction de la Santé Publique'.

130 e.g. see Welty, The Hunger Years, 24. Don Aminado Del Monte, Travel Notes: Souvenirs of the French Military Occupation Zone in Austria and Germany, 1945, 1946, 1947 and May 1948 (Karachi, 1951).

131 Lieutenant-Colonel W. Byford-Jones, Berlin Twilight (London, 1947), 25.

132 Foundation for Foreign Affairs, 'Field Report', 4.

133 Quoted in e.g. Kurt Klotzbach, Der Weg zur Staatspartei: Programmatik, praktische Politik und Organisationen der deutschen Sozialdemokratie, 1945-1965 (Berlin, 1982), 156.

134 Balfour, 'Four Power Control in Germany', 58.

135 Leon C. Standifer, Binding Up the Wounds: An American Soldier in Occupied Germany, 1945-1946 (Baton Rouge, La., 1997), 87, $146-7$.

136 German scholars have coined the term Vergleichsmentalität, or mindset inclined to comparisons. See e.g. Rainer Gries, Die RationenGesellschaft_-Versorgungskampf und Vergleichsmentalität: Leipzig, München und Köln nach dem Kriege (Münster, 1991).

137 Anna J. Merritt and Richard L. Merritt (eds.), Public Opinion in Occupied Germany: The OMGUS Surveys, $1945-1949$ (Urbana, 1970).

138 This phrase was in common usage in Britain and the United States. See e.g. Robert Eisler and Eric George Hart, Winning the Peace: A Comprehensive Policy (London, 1948). Keith Hutchinson, 'Germany's Steel Ration', The Nation, 162 (26 Jan. 1946), 100. Robert Vansittart, The Leopard and the Spots: Selected Extracts from 'Lessons of my Life' (Win the Peace Pamphlet No. 1, London [1944]), 51.

139 Falkenburger, 'Ich bin ein Berliner'.

140 COL AC 1031, Koenig to Commandant Supérieur des Troupes d'Occupation en Allemagne, 13 Dec. 1945.

141 COL AC 1031, Laffon to Monsieur le Général de Corps Armée, 5 Dec. 1945.

142 COL AC 1031, Laffon to Directors General, 1 Feb. 1947. Marriages between members of the French occupation forces and German civilians were still forbidden at this stage, but French officers could resign their posts and return to France with their German spouse. By September 1947, the ban on French-German marriages was formally lifted, see COL AC 1031, Koenig, 29 Oct. 1947.

143 Paul Falkenburger, 'Intervention: Souvenir de l'ancien curateur adjoint de l'université de Fribourg', in Manfrass and Rioux (eds.), France-Allemagne, 285.

144 Shortly before his expulsion from the Third Reich, the German-Jewish oncologist Ferdinand Blumenthal noted that French-German scientific collaborations had prospered for decades and had particularly enriched fields such as cancer research. Blumenthal, 'Avantpropos pour le chapitre concernant la lutte contre le cancer en Allemagne', in Jacques Bandaline, La Lutte internationale contre le cancer (Paris, 1933), 242-3. On his expulsion and move to Belgrade, see 'Ferdinand Blumenthal', Morgen, 15 July 1935. Blumenthal died in 1941.

145 TNA, FD 1/2483, 'Observations and Suggestions: Report on his visit to certain universities in the American and French zones, August 1946, by E. B. Strauss' [Aug. 1946].

146 See LAB B Rep. 012/5, Aktennotiz, 11 Mar. 1947, and note from Bezirksamtsarzt Reinickendorf, 2 Aug. 1947. 
147 COL AB 35/2, Le Général d'Armée Koenig, PIO le Général Navarre (Chef des Services de Direction), PA Le Lt.C-Colonel Henry (Chef de la Division d'Études et de Documentation), 'Note_-Objet: Articles de vulgarisation pour la presse française', 20 Jan. 1948.

148 COL AB 35/2, Desplats, 'La Direction de la santé publique'. Desplats is listed as the 'Chef du Service de Santé du GM' in Claude Albert Moreau and Robert Jouanneau Irriera, Présence française en Allemagne: Essai de géographie cordiale de la zone française d'occupation (Régie autonome des publications officielles avec le concours des Éditions Henri Neveu, 1949).

149 BAK, Z45F, 5/323-3/2, Philip Beckjord, 'Post-war Developments in the Public Health of Austria, 1945-1949’, 1949.

150 Willis, France, Germany and the New Europe, 41.

151 Foundation for Foreign Affairs, Field Report, 9-10.

152 Commandement en Chef Français en Allemagne, Recueil de documentation économique (Baden-Baden, 1949), chart 2. Commandement en Chef Français en Allemagne, La Zone Française d'Occupation, Janvier 1948, 47, also noted moderate improvements between 1946 and 1947.

153 Commandement en Chef Français en Allemagne, La Zone Française d'Occupation, Jan. 1948, 'Èchelle du rationnement en calories', 54.

154 TNA, FO 1050/687, Commission Interalliée de Nutrition, Section Santé Publique du Wurttemberg (Zone Française), Médecin Colonel Fabre.

155 Karl Brandt, Germany: Key to Peace in Europe (Claremont, 1949), 51. Brandt was initially based at the New School for Social Research, before joining the University of Stanford's prestigious Food Research Institute. He was a vocal critic of the Morgenthau Plan, see esp. Karl Brandt, Germany is Our Problem (Washington, 1946). Karl Brandt, Is There Still a Chance for Germany? (Hinsdale, Ill., 1949).

156 See reports quoted by Seidler, Die Medizinische Fakultät, 402.

157 TNA, FO 1050/687, Commission Interalliée de Nutrition, Section Santé Publique du Wurttemberg (Zone Française), Médecin Colonel Fabre.

158 M. Gerthoffer (French representative at the Nuremberg trials), quoted in Aron, The Vichy Regime, 430-1. Willis, France, Germany and the New Europe, 5.

159 GMZFO, Direction de l'Information, 'Le Rationnement en Allemagne', La France en Allemagne, 3 (1946), 47-50.

160 COL AEF 626, DG Agr et Rav to GMFZO Secretariat General, 19 Nov. 1948.

161 COL AEF 626, Ravitaillement to GM Rhein-Pfalz, 18 Oct. 1947. COL AEF 626, Zentralausschuss für Ernährung Baden-Baden to Chef de la Division de la production agricole et du Ravitaillement, 28 July 1948.

162 COL AB 35/2, Desplats, 'La Direction de la santé publique'.

163 FIAT, 'The Manufacture of Sulfonamides and Related Intermediates in the French, British and American Zones of Occupation, Germany', FIAT Final Report No. 915, London, 30 May 1947.

164 Phrase used by Gildea, France Since 1945, 6.

165 Stanley Hoffmann, 'The Trauma of 1940: A Disaster and Its Traces', in Joel Blatt (ed.), The French Defeat of 1940: Reassessments (Oxford, 1998), 365.

166 During Oct. to Dec. 1947 France received $£ 337$ million in emergency credits, followed by \$284 million of interim aid on 2 Jan. 1948 ; and a further $\$ 989$ million for the 12 months Apr. 1948-Apr. 1949. Willis, France, Germany and the New Europe, 20.

$167 \mathrm{LAB}, \mathrm{GMFB} / 114$, note on forthcoming increases in food rations in the French sector, 15 Oct. 1948.

168 COL AB 35/2, Desplats, 'La Direction de la Santé Publique’.

\section{(C) Jessica Reinisch 2013.}

This is an open access publication. Except where otherwise noted, this work is distributed under the terms of a Creative Commons AttributionNonCommercial- NoDerivatives 4.o International licence (CC BY-NC-ND), a copy of which is available at http://creativecommons.org/licenses/by-ncnd/4.o/ Enquiries concerning use outside the scope of the licence terms should be sent to the Rights Department, Oxford University Press, at the above address. 
Monographs, or book chapters, which are outputs of Wellcome Trust funding have been made freely available as part of the Wellcome Trust's open access policy

Bookshelf ID: NBK293857 